\title{
E-legislative and Accountability: The Case of Brazil
}

\author{
Rômulo Jose de Oliveira Zurra \\ University Professor; Parliamentary aide; Bachelor in Public administration at the UEA; Master in Public Administration at FGV/RJ \\ and member of the "Technologies of the Management" research group at Fundação Getulio Vargas (FGV/RJ); \\ email: romulozurra@yahoo.com.br \\ Lissandro Botelho \\ Professor at the Federal Institute of Amazon (IFAM); PhD student at Erasmus University Rotterdam; CNPq Fellow; \\ email: lissandro.botelho@gmail.com

\section{Sylvio Mário Puga Ferreira} \\ Professor at the Federal University of Amazonas (UFAM); Director of the Social Studies College (FES); \\ email: sylviopuga@hotmail.com

\section{Luiz Augusto Soares} \\ Professor at the UFAM; PhD student at Federal University of Minas Gerais (UFMG); \\ email: las10@uol.com.br
}

\section{Doi:10.5901/mjss.2013.v4n11p590}

\section{Abstract}

This article broaches the subject of Electronic Government, with a focus on its use in the 27 state legislatures of Brazil, concerning its use as a tool for public transparency. We sought to measure the level of transparency in the web addressess of these state legislatures. The measurement of the degree of transparency of the legislative web pages was carried out through the application of an electronic transparency measuring method, duly adapted, which are used by the non-governmental organization, Legislative Monitor, to monitor the websites of the legislature in Mexico based on the determinations of Complementary Law 131/2009 and Law 12.527/2011. The model took into consideration the availability of information on: administrative function; internal control; legislative work; work of the committees; concessions, permissions and contracts; historical archive and librarians services; external controls; e communication channels with the citizens. From this measurement a general ranking transparency was presented, demonstrating that $55.5 \%$ of the state legislative websites present insufficiency and low levels of transparency. Finally, the results of the research were correlated to other variables, with the intention of verifying if there were any degree of correlation between the variables analyzed and electronic transparency.

Keywords: transparency - e-gov - e-legislature - accountability

\section{Introduction}

The use of new technological resources allowed society to have new forms of Information and Communication Technology (TIC) use, the governement sector being one of the greatest inductors 0 strategic actions leading to an information society. The importance of the TIC in the modern organizations has created, especially in the last few decades, inestimable differential in the methods, processes, and in the structural-administrative concept itself of the same. Besides the initial benefits, being economy of time, resources and raw material. The TIC also represented innumerable qualitative gains in the productive activity and the rendering of services. Such technologies became, despite a certain delay, a part of public organizations' set of administrative tools. However, the rigid bureaucratic parameters, where the rational-legal perception rules, and, sometimes, substitutes the attempts towards a more innovative strategical reasoning, had conferred upon the technological advances in the scope of public administration quite a slow rhythm in compared to private organizations. Centralization, maintenance of the statuses quo, formalism and innumerable other burocratic disfunções in the public machine, were belatedly perceived as incongruous to the elementary advances that 
can be fostered in the governmental structures with the use of TIC.

However, based on the technological advance and the rise of the Internet, that broadened the possibility of sharing of data and information and, above all, made possible and facilitated the systems integration process in a more homogeneous environment, TIC, increasingly leaves behind being merely an support instrument for bureaucratic activities, also being used as strategical tool of the public organizations, becoming a powerful ally in the implementation of governmental actions.

Thus, the Internet becomes an affable communication channel governments use as a strategy to improve the public rendering of services and to invest heavily in this instrument that can greatly facilitate the easy and equitable access to various services and governmental actions. Thenceforward, a more democratic environment can be conceived, where everyone can have access to any type of information at any time. In the State vs. Society relationship, the Internet presents itself as a very favorable channel to establish a strong trust-based relationship between the citizens and the State.

On the other hand, today the population also has been demanding greater transparency on the part of the governments and seeking ever increasing information, especially on the use of public resources. Consequently, the Internet constitutes a strategic tool where the proper citizen himself can accompany the activities of the State, therefore "the right to access information generated or withheld by the public sector became one of the cornerstones in the effort to extend the transparency of the State and to make the detainers of public offices more responsible ", (ABRAMO apud KONDO [et al.] 2002, P. 203).

1659 Thus we highlight the role of the Legislative Branch in this context, as a legislator, controller and inspector of the Executive branch's actions. The Legislature currently makes use of the modern TIC tools and needs to use it to follow the governmental acts, supplying the citizen with the necessary information on the management of the public goods and treasure. To that end, this information must, at the least, be made available on the Legislative website, as well as the information on the administration of the Legislative House itself.

Considering this perspective compels this article to discuss the systems of electronic governance used by all State Legislatures of Brazil, the main target being the measurement of the degree of transparency that these websites make available to citizens. Thus, the websites of all 26 State Legislatures of Brazil and the Legislative chamber of the Federal District, will be analyzed to answer the following question: What is the degree of transparency of the State Legislatures websites in Brazil?

\section{E-Gov as an Instrument of Accountability}

The last decades of the 20th century presented changes in the paradigms of public administration, with the emergence of new models, such as the manageriall one, that gave greater emphasis to the control of the results, instead of the means. At the same time, according to JOSE VAZ (2002), the redemocratização process, strongly stimulated by the Constitution of 1988, stimulated a significant pressure from society for transparency in the government. This same redemocratização may have led society to a firmer posture of demand for better quality public services. These transformations provided the use of new tools that greatly helped the government to meet the demands of the rules established by the managerial paradigm and the Constitution of 1988, among them, the use of TIC stands out.

The use of the TIC by the public administration to interact with society and private institutions, either in carrying out its end or means activities, and especially, in the rendering of services or in making information available came to be called e-gov.

Jose Vaz (2002, P. 16) shows this when he affirms that the TIC constitutes in an important instrument of support for the public administration, by allowing the offer of new services to the citizen, offering conditions for broadening the efficiency and the effectiveness of public services, improving the quality of these services and further allowing access to information and the formation of new standards of relationship with citizens and new spaces to promote citizenship.

However, with the introduction of the rules posed by accountability, as to the obligation of the public managers to render accounts to society. Nevertheless, one observes that the use of information tools arose to facilitate this process, in view of the apparatuses and managerial systems that assist the managers in the fulfilment of their activities. From this perspective, the Internet also presents itself as an important tool, since it makes it possible for citizens to access varied services without the necessity of leaving the house. Another important contribution of the information systems, the Internet in particular, to accountability is that it allows the citizen to follow the activities of the public servants, besides being used to render accounts, where the government, by means of its websites, can make available all types of information to be accessed by the population. 
On the other hand, the simple introduction of the precepts of accountability supported by the tools of e-gov does not guarantee the full exercise of citizenship and of social control. For such, it is necessary that a cultural change of the citizens be observed. DAHL (2001) affirms that from the moment when a type of citizen is born, who is effectively able to participate in the public thing, demands for accountability as an instrument of popular sovereignty control of the acts of the elected representatives and the public servants in general will be formulated.

Akutsu \& Pine (2002) argue that the social control and the formal controls are closely tied. Only with fullaccountability, that is, with public information and trustworthy renderings of accounts on the part of the governers, duly audited by external and internal controls of the public agencies can citizens actively participate in public decisions. On the other hand, without an organized civil society, the public managers will not feel obliged to promote accountability. The social control can, therefore, fortify the legally instituted formal control, leading society to more actively participate in public life and thus reduce the distance between government performance and the actual needs of the citizens.

For this transformation to be accomplished, strengthening of accountability on the part of the managers and the incorporation of this concept in the culture of society is primordial. Thus, in a society with full accountability, one expects that the public managers give to accounts of their actions, making the decisions and actions that interest the collectivity public, such as the of budget statements; ample advertising public tenders, indicating the selected suppliers and the prices of the winning proposals; and indication of the services and programs offered by the government. In more advanced stages of democracy, one expects that, besides the transparency of the results obtained by the administration, the main governmental decisions - such as the elaboration of the budget and the public tenders for public projects and services of greater reach - always be made only after consulting society through public audiences.

Therefore, what can be arugued is that with the full use of the precepts of accountability supported by the e-gov tools, the public administration can provide its citizens greater access to public information. For Sanchez (2003, p.29) this availability of information is a democratic conquest. The governing bodies generally dose out information from droppers and, even so, they hide what they consider "strategic". Any and all information can easily be considered "strategic" and, in most cases, concealing information becomes the rule and not exception. There is still a long way to go, but it could be shortened if society were to pressure for the opening of information contained in the new informacion systems.

It is worthwhile to remember that the production and regular transmission of information concerning public policies (government actions) are vital for control or participation, even of the organized segments of society, as the governmental transparency also depends on the degree of freedom of the press, allowing the discussion and freedom of opinion (Clad, 2000).

Therefore, in a democracy it is supposed that political power comes from society as a whole and that each citizen participates in making collective decisions. Therefore, it is understood that all the decisions must be public, in the double sense that the process that leads to them is open to ample participation and the content is accessible to all. The consequence of this principle is the demand for a high degree of transparency in politica decision making (CLAD, 2000).

Thus, the diffusion of public information constitutes one of the basic conditions for the success of the accountability cycle, since if the citizens have very incomplete information on the actions of the public power, they will face difficulties in evaluating the governance. The tools of e-gov must be used in this perspective so that society is always armed with information on how the public thing is being managed. $E$ in this process, it makes sense to highliight the role of the Legislature in the transparency of public administration, as will be seen next.

\section{E-Legislature as a Transparency Tool in the Brazilian Public Administration}

The Legislative Houses, regarding the principle of separation of powers and autonomy of public entities, in constitutional terms, and comprehending their jurisdiction and scope, have as incumbencies: rendering and taking of accounts with the government; the ascertainment of crimes by politicians, through due process of law; convening secretaries of State, other political players, legal representatives of third sector entitiesr, that perceive and manage state goods or resources and other entities who offer public services, by means of public concessions; effectting ownership and establishing subsidy for the governor and the lieutenant governor of the State; the appraisal of nominations subject to the deliberation of the Legislative Branch; e, other themes defined by law.

Consequently, one can affirm that motivated by the changes in posture imposed by new administrative paradigms and especially the emergence of TICs, that stimulated the legislative branch to act as an agent of accountability, the Brazilian legislature needed to seek new tools that could facilitate and improve the fulfilment of its tasks. Not withstanding, the legislature also had that to adopt informational tools that the executive branch had already been using, the combination of which came to be called e-gov or electronic government. In the scope of the Legislative Branch this 
tool was named of e-legislature.

Currently all State Legislatures in Brazil have webpages, where information such as daily news on the parliamentary actions, members' of the house of representatives schedules, order of business, anual and bi-anual reports parliamentary and committee activity, house of representatives attendence statistics, budget performance, along with other information, is made available. However, the release of this information varies greatly among state Legislative Houses, some releasing a reasonable amount of information and others a still just beginning, and insuficiently.

A positive aspect of these websites is that they also provide a communication channel between society and the Legislative House and with the members of the house of representatives, a fact that facilitates contact with branch, still considered by many, as distant from the population, especially residents far from the states capitals, since the state Legislative House establishes its headquarters there. Due to this distance, a great part of the population can only follow the performance of the parliamentarians, through the media, among them the legislative body's websites, which present themselves as one of the most complete means of contact between the population and the legislature.

As MAIA (2002) affirms, the new information and communication technologies, including the Internet, seems to offer various advantages over the democratic medias, since its interactive and multi-functional devices offer "new possibilities for decentralized participation". As the author affirms, these new technologies allow different partners of interlocution to be in contact, through reciprocal actions and virtual bonds, creating an unknown potential for interaction. This is not just about isolated conectividade of the web-user in contact with the government, for example, but the potential of collective connection, approaching citizens through chats and discusssion groups.

Thus, these websites are an excellent information and transparency tool for the acts of the Legislative Branch, since one of the main functions of the electronic government is transparency, which uses the tool box of the TIC, especially the Internet, to inform citizens on the actions that the organ is carrying out and how many resources, be they material, human or financial, are being expended in achieving the goals of the entity.

Thus, the use of Internet also becomes a support tool to the legislature in the achievement of its role of overseeing agent of the executive branch, which, if fully explored, can allow this Branch to truely becomes an agent of accountability. The responsability thus falls to the Legislature to not only divulge information concerning its own actions, but also those of the Executive Branch.

In this context, is important to highlight an important difference in the use of informacion systems, especially the Internet, between the Executive and the Legislative Branches, where the first may make use of these systems to render services to society, such as issuing barcodes to pay fees and taxes, school registration, payment of fines, etc. The use of the internet by the Legislature, on the ther hand, exercies mainly informative, supervisory and control functions. Therefore, transparency is the main function of e-legislature. Thus it is essential that these state legislatures actually use e-legislature as a tool for control, oversight and discloure of its actions and the actions of the Executive Branch. However, without the introduction of specific regulation in each Legislative House that compels its president to disclose what is considered minimum information, the decision of what it will be at the disposal of the population will still be left to the criteria of these presidents. Faced with this, the following process of regulation of the transparency in some countries of America presented itself.

\section{The Law of Public Transparency and Access to Public Governmental Information}

One should note the importance of passing and applying a law that guarantees the citizen greater ease of access to public information, since one of the principles of public administration is legality, that causes the acts of the public administrator to be buoyed up through laws, decrees, resolutions, ordinances, etc. Consequently, the Brazilian Constitution forsaw the publication of public information, however, it was still necessary to introduuce a more specific legislation, that compelled the public servant to divulge data inherent to public administration, as well as specify which information should be divulged, this being necessary to provide greater uniformity in publishing this information among the different agencies of public administration and especially so that the citizen can know what documents and information the public manager should supply.

Thus, on the 27th of May, 2009 the Complementary Law 131/09 came into effect, which compeled all public agencies belonging to the three branches of the Federation to make available, in real time, information on its budgetary and financial executions. Added to this Law the Usual Law 12,527/2011 also came into effect on May 26th, 2012, known as the Law of Access to Information - LAl, which establishes that the public entities must divulge on the Internet, in clear language and with ease of access, data on public administration.

On the Internet one must be able to find, at least, a record of the organizacional structure and scope, addresses 
and telephone numbers of the respective units and hours they are open to the public. Records must also be published of any transfer of financial resources and information on public tenders, including the proclamations and results. The law requires that general data be displayed on the Internet allowing the accompaniment of governement programs, actions, projects and construction, besides answers to the questions most frequently asked by society.

A panorama of this subject is shown here, demonstrating how this process occurred in the United States and other countries of Latin America, which already possess specific legislation on the subject and were chosen because they present certain similarities to Brazil, such as the political-economic system, of government, and territorial proximity, among others.

In the United States the freedom of information and the "Sunshine" laws are the two main governmental initiatives in combating corruption. $\mathrm{E}$ one of the main artifices of the American strategy was the creation of the Freedom of Information Law - Foia. Approved first in 1966. This Law determines that the government documents are, in essence, property of the people and that the population retains the right to access them. The Foia inverts the traditional burden of proof, switching from the hypothesis that the documents are confidential until the citizens establish basis to access them, to the hypothesis that the documents are public until the government establishes a basis (such as national security and personal privacy) to keep them confidential. Hence Foia elaborated an important premise, in which posterior reforms have been made: that the citizens have the right to know their government and to know what was being done.

In Latin America Colombia is a pioneer in adopting legislation on access to public information, which came into effect July 5th, 1985, with the introduction of Law 57 , which granted to all persons the right to consult documents in power of State offices and to receive a copy of these documents.

On January 22nf, 2002, Law $n^{0} 6$ was enacted in Panama, on transparency in the government, which states that all legal entities have the right to ask information of the government agencies and the staff member concerned has 30 days to provide this information. The noncompliance of the employee leads to fines or dismissal from employment. The law establishes nine cases of "restricted access", among them the ones that are related to information on national security and the cases being investigated by the Solicitor-General.

On August 2nd, 2002, the Peruvian President, Alejandro Toledo, officially enacted the Law of Transparency and Access to Public information, that then was published on August 3rd, 2002 in the El Peruano official gazette. Although this law represents an important advance for the right to information, it behooves us to mention its article 15 , that refers to the exceptions that the law grants to the Executive Branch to classify information as "private and strictly confidential" for reasons of national security, since this procedure would grant the ministerial cabinet, an eminently political entity, the ability to classify information as restricted. On August 6th, 2003 the regulatory decree of the Law of Transparency and Access to the Public Information came into effect. This Regulation was promoted by the committee created by law to fulfil provisions of the same.

In Mexico, suggestively named "Ley de Transparencia", was approved on June 11th, 2002, but the Mexican Congress had the prudence to give it one year to take effect so that the public agencies could adapt to the new rules. The Law was also one of Vicente Fox Presidential campaign promises in 2000. The new law foresees that all the State organs place to the citizens' disposal information that allows them to know the functions, actions and resources of the government. Documents that can affect the national security are excluded.

In May of 2004 it was Equator's turn, with the approval of Congress. The Law of Disclosure and Access to Information grants the citizens access to information in the power of agencies of the public sector, with the exception of information of a personal nature or that has been classified as such by a competent public officer. The law further guarantees access to information in the possession of public and private entities that have public information, with the exclusion of personal data.

In Argentina, enacted in 2004, the law offers a general guarantee of access to information, allowing the Argentineans access to the databases of official agencies. The law establishes administrative and legal penalties for the public officers who do not comply with the requests. It also confers public character to the laws, decrees and documents that have been kept secret by the State for over 10 years without having been classified as restricted.

In Honduras the law was approved on November 27th, 2006, after pressure from the Committee for the Liberty of speech - C-Free, which carried out a Regional Dialogue in the city of Choluteca on the subject of the "Right to the information in the national scenario". Two similar meetings had been carried out in other regions of Honduras. In the course of this conference, the local limitations faced by the journalists, social communicators and the citizens to gain access the information of public interest were examined. $\mathrm{E}$ in this meantime $\mathrm{C}$-Free presented a draft bill on Access to Public Information and the habeas data appeal.

According to Transparency International, Chile stands out as one of the countries with lowest levels of corruption 
on an international level, and lowest in this aspect in Latin America. In this context the main measures adopted by Chile were: the formation of the National Public Ethics Committee in 1994; the establishment of the Law of Administrative Probity in 1999; the elaboration of the Pro Transparency Agenda in 2003; besides the approval of the law known as Law of Public Transparency and Access to Governmental Information in 2007.

\section{Methodology and Presentation of the Results}

Research on electronic transparency in the Legislatures of the Brazilian states established the report on electronic transparency from the Mexican Congress, which is made by the Non-Governmental Organization, Legislative Monitor, as a baseline model. The report analyzes a set of items required by the Law of Transparency and Access to Governmental Public Information in Mexico, instituted on June 11th, 2002, and also of the Legislative Resolution by the Mexican Congress, that detailed the requirements already made in the Complementary Law. Hence, the model used in this research underwent some adaptations, integrating items and sub-items not observed in the original model, since further items were added that are considered obligatory in the Complementary Law 131/2009 and Usual Law 12,527/2011, respectively the Law of Transparency and the Law of Access to Information. Some of these were observed in some state legislature's websites in Brazil, which were not contemplated in the Mexican model. The model built observed 8 items, which had been researched in all 27 Brazilian State Legislatures in the period between 06/ 29/2013 and 07/13/2013. The items analyzed are:

A. Administrative role: it seeks to observe if the state parliaments place information on its administrative structure (organic structure, abilities of the sectors, list of public servers, remuneration of the servers, objectives and goals of the administrative units) at the disposal of the society ;

B. Internal control: it intends to observe the parliamentary performance and the audits carried out in the scope of the agency (information on material goods, report on fiscal management, allocation of financial resources, funding of staff and indemnity, annual report on transparency, results of audits, complaints against member of the house of representatives and disclosure of the budgetary execution in real time - as stated in Law 131/2009);

C. legislative Work: its purpose is to analyze if there is availability of information on the legislative works (order of business, parliamentary gazette, propositions, roll call votes, information of official trips and resources, Web channel and parliamentary attendance);

D. Work of the committees: its target is to verify if information is available on the works of the legislative committees (members of the committees, results of inquiries, work reports of, committee reports);

E. Concessions, permissions and contracts: it seeks to observe if information is available on the public bidding process in the scope of the Parliaments researched (concessions and permissions; information on contracts: acquired or leased goods and the services that are being contracted; the price of contracts; the name of the contracted party and deadline for contract fulfillment);

F. Historical archive and librarian services: it seeks to analyze whether the legislatures have adopted criteria for cataloguing and classifying documents, as well as rendering librarian services, making the procedures, requirements and formats explicit for the good use of the historical archive and the virtual library ;

G. External Controls: The goal here is to analyze if the legislatures State make information available on the acts of the Executive Branch of its respective State (State Master Budget, link for sites of other organs and the Official Gazette);

$\mathrm{H}$. Communication channel with citizens: it seeks to observe if means of interaction with the society are made available (channel of contact with the parliamentary ombudsman, lists of the main questions and answers, a channel for complaints, information request forms as required by Law 12,527/2011).

\section{System of Weights}

As seen previously, the model is composed of 8 items, in which 40 are distributed sub-items. With the end goal of facilitating data tabulation, keeping in mind that the model has a considerable number of sub-items, was decided to adopt only three measurements, which are: 0 When the agency not make available what it is being verified; 1 when what is being verified possess a reasonable availability; and 2 when the agency satisfactorily makes available what is being verified.

Therefore, having 40 sub-items distributed within the 8 items, the adoption of the system of weights as described 
above, would provide a total result of 40 points if the Legislative House reasonable fulfilled all the analyzed requirements and 80 points, if the analyzed parliaments fulfilled all sub-items satisfactorily. Hence, adopting as maximum 10 as the maximum score (of the whole), the model adopts a system of weights as follows: $0=0 ; 1=0.125$ and $2=0.25$.

Thus it is evident that the item with the greatest number of sub-items must receive a higher score, as described below:

Picture 1. Maximum score per item

\begin{tabular}{|c|c|c|c|c|}
\hline & Item & $\mathrm{N}^{0}$ de Sub-items & 0.125 & 0.25 \\
\hline A) & Administrative Role & 5 & 0.625 & 1.25 \\
\hline B) & Internal control & 8 & 1 & 2 \\
\hline C) & Legislative work & 7 & 0.875 & 1.75 \\
\hline D) & Work of the committees & 4 & 0.5 & 1 \\
\hline E) & Concessions, permissions and contracts & 6 & 0.75 & 1.5 \\
\hline F) & Historical archive and librarian services & 3 & 0.375 & 0.75 \\
\hline G) & External Controls: & 3 & 0.375 & 0.75 \\
\hline H) & Communication channels with the citizens & 4 & 0.5 & 1 \\
\hline & Score & 40 & 5 & 10 \\
\hline
\end{tabular}

And to measure the transparency per item, it was necessary, first, to construct a transparency continuum, in which 4 levels were established, classified according to the percentage of the requirements of the analyzed item were met (ratio measurement).

By means of the transparency continuum it was possible also to fashion a transparency ranking, where the state legislatures' websites were arranged in order of acquired points, using as a tie-breaker the websites with a higher score in item "E" - concessions, permissions and contracts, since they are the main item required by Law 131/09 and Law $12.527 / 2011$.

Picture 2. Transparency continuum

\begin{tabular}{|l|c|c|}
\hline Level of Transparency & Percentage of requirements met & Quartile \\
\hline Satisfactory & $75 \%$ to $100 \%$ & $4^{\circ}$ \\
\hline Reasonable & $50 \%$ to $74.99 \%$ & $3^{\circ}$ \\
\hline Low & $25 \%$ to $49.99 \%$ & $2^{\circ}$ \\
\hline Insufficient & $0 \%$ to $24.99 \%$ & $1^{\circ}$ \\
\hline
\end{tabular}

Thus based on this methodology, the set of results attained are presented.

Table 1. Score per item and level of transparency

\begin{tabular}{|c|c|c|c|c|c|c|c|c|c|c|c|}
\hline Order & $\begin{array}{c}\text { State } \\
\text { legislature }\end{array}$ & Administr & Internal & Legislative & Work of the \\
ative Role & control & $\begin{array}{c}\text { Concessions, } \\
\text { permissions } \\
\text { committees }\end{array}$ & $\begin{array}{c}\text { Historical } \\
\text { and contracts } \\
\text { and } \\
\text { and } \\
\text { librarian } \\
\text { services }\end{array}$ & $\begin{array}{c}\text { External } \\
\text { Controls: }\end{array}$ & $\begin{array}{c}\text { Channel } \\
\text { to the } \\
\text { citizens }\end{array}$ & $\begin{array}{c}\text { Final } \\
\text { Score }\end{array}$ & $\begin{array}{c}\text { Level of } \\
\text { Transparency }\end{array}$ \\
\hline 1 & $\begin{array}{c}\text { Rio Grande } \\
\text { Do Sul }\end{array}$ & 1 & 1.625 & 1.75 & 1 & 1.5 & 0.75 & 0.625 & 1 & 9.25 & Satisfactory \\
\hline 2 & $\begin{array}{c}\text { Rio De } \\
\text { Janeiro }\end{array}$ & 0.75 & 1.125 & 1.625 & 0.75 & 1.5 & 0.5 & 0.5 & 0.75 & 7.50 & \\
\hline 3 & $\begin{array}{c}\text { Santa } \\
\text { Catarina }\end{array}$ & 1 & 1 & 1.5 & 0.375 & 1.5 & 0.75 & 0.375 & 0.625 & 7.13 & \\
\hline 4 & São Paulo & 0.625 & 1.125 & 1.25 & 0.625 & 1.5 & 0.625 & 0.375 & 0.375 & 6.50 \\
\hline 5 & Mato Grosso & 0.875 & 0.75 & 1 & 0.375 & 1.5 & 0.5 & 0.25 & 0.875 & 6.13 \\
\hline 6 & Minas Gerais & 0.75 & 1.125 & 1 & 0.375 & 1.5 & 0.5 & 0.125 & 0.625 & 6.00 \\
\hline 7 & Paraná & 0.75 & 0.875 & 1.625 & 0.625 & 0.875 & 0.375 & 0.5 & 0.375 & 6.00 \\
\hline 8 & Amazonas & 0.375 & 0.625 & 1.125 & 0.5 & 1.375 & 0.5 & 0.625 & 0.375 & 5.50 & \\
\hline
\end{tabular}




\begin{tabular}{|c|c|c|c|c|c|c|c|c|c|c|c|}
\hline 9 & Ceará & 0.75 & 0.75 & 1 & 0.75 & 0,75 & 0.5 & 0.5 & 0.375 & 5.38 & \\
\hline 10 & Bahia & 0.625 & 0.5 & 1.125 & 0.75 & 1.25 & 0.125 & 0.25 & 0.375 & 5.00 & \\
\hline 11 & $\begin{array}{l}\text { Espirito } \\
\text { Santo }\end{array}$ & 0.875 & 1 & 1.125 & 0.125 & 0.75 & 0.375 & 0.5 & 0.25 & 5.00 & \\
\hline 12 & Paraíba & 0.75 & 0.375 & 0.75 & 0.625 & 1.5 & 0.5 & 0.25 & 0.25 & 5.00 & \\
\hline 13 & Rondônia & 0.5 & 0.625 & 1.25 & 0.375 & 1 & 0.5 & 0.5 & 0 & 4.75 & \multirow{11}{*}{ Low } \\
\hline 14 & Pará & 0.125 & 0.5 & 0.75 & 0.625 & 1.5 & 0.375 & 0.125 & 0.25 & 4.25 & \\
\hline 15 & $\begin{array}{c}\text { Federal } \\
\text { district }\end{array}$ & 0.625 & 0.25 & 1 & 0.375 & 0.875 & 0.75 & 0 & 0.125 & 4.00 & \\
\hline 16 & Pernambuco & 0.625 & 0.25 & 1.125 & 0.875 & 0 & 0.625 & 0.5 & 0 & 4.00 & \\
\hline 17 & $\begin{array}{l}\text { Rio Grande } \\
\text { do Norte }\end{array}$ & 0.75 & 0.625 & 0.75 & 0.375 & 0.75 & 0.25 & 0.125 & 0.125 & 3.75 & \\
\hline 18 & $\begin{array}{c}\text { Mato Grosso } \\
\text { do Sul }\end{array}$ & 0.25 & 0.75 & 0.5 & 0.375 & 0.75 & 0.375 & 0.5 & 0.125 & 3.63 & \\
\hline 19 & Sergipe & 0.625 & 0.375 & 0.75 & 0.375 & 0.75 & 0.25 & 0.125 & 0.375 & 3.63 & \\
\hline 20 & Goiás & 0.125 & 0.5 & 0.5 & 0.625 & 0.875 & 0.375 & 0.375 & 0.125 & 3.50 & \\
\hline 21 & Tocantins & 0.5 & 0.5 & 0.5 & 0.375 & 0.75 & 0.125 & 0.25 & 0.5 & 3.50 & \\
\hline 22 & Amapá & 0.375 & 0.625 & 1.125 & 0.25 & 0.5 & 0.125 & 0 & 0.375 & 3.38 & \\
\hline 23 & Maranhão & 0.375 & 0.25 & 0.75 & 0.125 & 0.75 & 0.125 & 0.125 & 0 & 2.50 & \\
\hline 24 & Piauí & 0.375 & 0.5 & 0.625 & 0.125 & 0 & 0 & 0.375 & 0.375 & 2.38 & \multirow{4}{*}{ Insufficient } \\
\hline 25 & Roraima & 0.25 & 0.625 & 0.125 & 0 & 0.75 & 0.125 & 0.125 & 0.25 & 2.25 & \\
\hline 26 & Acre & 0.375 & 0.125 & 0.625 & 0.125 & 0.375 & 0.125 & 0.125 & 0 & 1.88 & \\
\hline 27 & Alagoas & \multicolumn{8}{|c|}{ Website off-line at the time of the research $(06 / 29 / 2013$ to $07 / 13 / 2013)$} & 0.00 & \\
\hline
\end{tabular}

\section{Analysis by item}

\subsection{Administrative Role}

In this item, $18.5 \%$ of the websites were classified as having insufficient transparency; $26 \%$ a low level; $48 \%$ reasonable; and only $7.5 \%$ qualified as satisfactory. The best score went to the Legislatures the Rio Grande Do Sul and Santa Catarina, which met $80 \%$ of the requirements. As to the general level, the group was classified as low.

\subsection{Internal Control}

In this item, $26 \%$ of the websites were classified as having insufficient transparency; $52 \%$ a low level; $18 \%$ reasonable; and only $4 \%$ qualified as satisfactory. The best score went to the Legislature of Rio Grande Do Sul's website, which met $81 \%$ of the requirements. As to the general level, the group was classified as low.

\subsection{Legislative Work}

On this point, we found the following classification: $8 \%$ of the websites were found with an insufficient level of transparency; $37 \%$ at low level; $41 \%$ at a reasonable level; e 14\% at a satisfactory level. The best score went to Rio Grande Do Sul, that met $100 \%$ of the requirements. As a whole the group was classified as having a reasonable level of transparency.

\subsection{Work of the Committees}

The item in question had the following classification: In this item, $22 \%$ of the websites were classified as having insufficient transparency; $36 \%$ a low level; $22 \%$ reasonable; and $19 \%$ qualified as satisfactory. The best score went to the Legislature of Rio Grande Do Sul's website, which met $100 \%$ of the requirements. As a whole the group was classified as having a low level of transparency.

\subsection{Concessions, Permissions and Contracts}

In this item, $11 \%$ of the websites were classified as having insufficient transparency; $8 \%$ a low level; $44 \%$ reasonable; 
and $37 \%$ qualified as satisfactory. Eight websites met $100 \%$ of the requirements. Three websites did not register a score. As a whole the group was classified as low.

\subsection{Historical Archive and Librarian Services}

On this point, we found the following classification: $30 \%$ of the websites were classified as having insufficient transparency; $8 \%$ a low level; $44 \%$ reasonable; and 18\% qualified as satisfactory. The best score went to the Legislatures the Rio Grande Do Sul, Santa Catarina and the Federal District, all of which met $100 \%$ of the requirements. Two websites did not score. The group as a whole was classified as low.

\subsection{External Control}

In this item, $37 \%$ of the websites were classified as having insufficient transparency; $15 \%$ a low level; $44 \%$ reasonable; and $8 \%$ qualified as satisfactory. The best score went to the Legislatures the Rio Grande Do Sul and Amazona, which met $83 \%$ of the requirements. Three websites did not register a score. As a whole the group was classified as having a low level of transparency.

\subsection{Communication Channels with the Citizens}

In this item, $33.5 \%$ of the websites were classified as having insufficient transparency; $44.5 \%$ a low level; $11 \%$ reasonable; and $11 \%$ qualified as satisfactory. The best score went to the Legislature of Rio Grande Do Sul's website, which met $100 \%$ of the requirements. Five websites did not score. As a whole the group was classified as having a low level of transparency.

\section{General analysis}

Analyzing the data above, one can conclude that only $7.5 \%$ of the state legislative websites in Brazil, ie. only the legislative websites of Rio Grande Do Sul and of Rio De Janeiro, possess a satisfactory level of transparency, which means that the websites of the legislatures of these states, make available $75 \%$ or more of the researched items. The State Legislatures of Santa Catarina, São Paulo, Mato Grosso, Minas Gerais, Paraná, Amazonas, Ceará, Bahia and Espirito Santo, which represent $37 \%$ of the universe of the study, were classified as having a reasonable level of transparency, being that they made available up to $74.99 \%$ of the items researched. The legislative websites from Rondônia, Pará, Federal District, Pernambuco, Rio Grande do Norte, Mato Grosso do Sul, Sergipe, Goiás, Tocantins, Amapá and Maranhão, representing $40.7 \%$ of the total researched, were classified as having a low level of transparency, since they make available up to $49,99 \%$ of the researched items. And finally, the legislative websites from Piauí, Roraima, Acre and Alagoas that represent $14.8 \%$ of the research universe were classified at an insufficient level of transparency, since they made available lesss then $24,99 \%$ of the researched items.

So, analyzing this general classification based on descriptive statistics, we find: that the greatest score (upper limit) was 9.25, obtained by Rio Grande Do Sul. The lowest score (inferior limit), on the other hand, was 1.88, given to the state of Roraima and Alagoas, which zeroed the researched items, due to the fact that their websites were off-line throughout the period of the research (06/29/2013 through 07/13/2013).

Therefore, the group average was 4.25 points and the standard deviation was 1.95 . Thus, we found the following distribution around the group average:

Up to 2 units of standard deviation $=96.3 \%$ of the websites

Up to 1.5 units of standard deviation $=90 \%$ of the websites

Up to 1 unit of standard deviation $=74 \%$ of the websites

Up to 0.5 unit of standard deviation $=48 \%$ of the websites

Through this analysis it is observed that the distribution of the values is quite symmetrical around the average, which is 4.25 points.

This means that the scores varied very little in relation to the average, that is, that a great part of the received scores very near the group average. Thus, $90 \%$ of these scores are concentrated in the $(1.32 ; 7.17)$ points interval, corresponding to 1.5 units standard deviation. A ratio of values above of 7.17 points is low (7.4\%), which exceeded the mark of two units of standard deviation in relation to the average, these being from the legislatures of Rio Grande Do Sul 
and Rio De Janeiro. Another important fact is that $51.8 \%$ of the websites obtained a score equal to or greater than the average and the other $48.2 \%$ received a score below it.

Thus we can conclude that in general the group score was low, explained by the considerable ratio of websites with below average scores. Making a general classification based on the observed average, we see that it also is classified as low, since it belongs to the 2 nd quartile $=25 \%$ to $49.99 \%=$ low level of transparency.

However, it is necessary that relate data obtained to other variables, which will be able to better explain or to clarify the score obtained by the state legislative websites.

\subsection{Relation to Other Indicators}

The research also correlated the final result of the electronic transparency in legislatures with the Index of Human Development - IDH (2008) and with the percentage of people who have access to the Internet in the Brazilian states, elaborated by the IBGE (National Research of Sampling per Domicile - the PNAD/2011).

The statistics tool used for this verification was correlation, since it takes the role of measuring the force of relation or association between two variable, by means of the correlation coefficient.

Table 3. Relation with other Indicators

\begin{tabular}{|clccc|}
\hline & \multicolumn{1}{c}{ State } & Transparency & IDH (2008) & \% access to the Internet (2011) \\
\hline 1 & Rio Grande Do Sul & 9.25 & 0.832 & 48 \\
2 & Rio De Janeiro & 7.5 & 0.832 & 54.5 \\
3 & Santa Catarina & 7.125 & 0.84 & 52.1 \\
4 & São Paulo & 6.5 & 0.833 & 59.5 \\
\hline 5 & Mato Grosso & 6.125 & 0.796 & 49.5 \\
6 & Minas Gerais & 6 & 0.8 & 43.6 \\
7 & Paraná & 6 & 0.82 & 51.1 \\
\hline 8 & Amazonas & 5.5 & 0.78 & 37.3 \\
9 & Ceará & 5.375 & 0.723 & 33.4 \\
10 & Bahia & 5 & 0.742 & 37.2 \\
11 & Espirito Santo & 5 & 0.802 & 48.5 \\
12 & Paraíba & 5 & 0.718 & 38.4 \\
\hline 13 & Rondônia & 4.75 & 0.756 & 42.8 \\
14 & Pará & 4.25 & 0.755 & 30.7 \\
15 & Federal District & 4 & 0.874 & 71.1 \\
16 & Pernambuco & 4 & 0.718 & 37.2 \\
17 & Rio Grande do Norte & 3.75 & 0.738 & 36.5 \\
18 & Mato Grosso do Sul & 3.625 & 0.802 & 51.7 \\
19 & Sergipe & 3.625 & 0.742 & 34.5 \\
20 & Goiás & 3.5 & 0.8 & 47.7 \\
21 & Tocantins & 3.5 & 0.756 & 38.2 \\
\hline 22 & Amapá & 3.375 & 0.78 & 41.1 \\
23 & Maranhão & 2.5 & 0.683 & 24.1 \\
24 & Piaúl & 2.375 & 0.703 & 24.2 \\
25 & Roraima & 2.25 & 0.75 & 48.1 \\
26 & Acre & 1.875 & 0.751 & 40.8 \\
27 & Alagoas & 0 & 0.677 & 34.3 \\
\hline
\end{tabular}

Source: Elaborated by the authors, 2013.

\subsection{Relation of electronic transparency with IDH}

This analysis consists of verifying the degree of correlation of electronic transparency with the Index of Human Development (2008); that is, the intention is to see if the States that possess a good performance in IDH, also have a good performance in electronic transparency.

Thus, we present the graph of dispersion and the coefficient of correlation to verify the hypothesis formulated above. 
Graph 01. Relation of IDH X Transparency

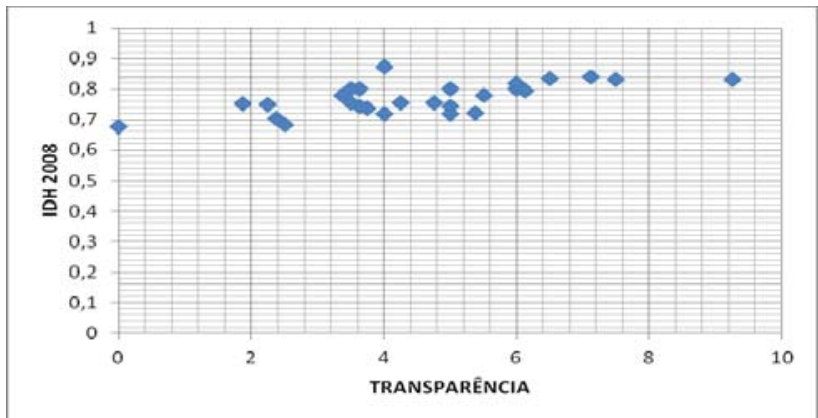

Source: Database of IDH - 2008. Coefficient of correlation $=0.66$

Analyzing the graph, one can note that there is a positive correlation between the two variables, that is, the states that get high scores of $X$ tend to get high scores of $Y$. This does not yet mean that the hypothesis was confirmed; to that end it is necessary to test the intensity of the correlation.

To do the intensity test it is necessary to observe the coefficient correlation, which indicates numerically indicates both the direction and intensity of the linear correlation. It can vary from -1 to +1 . The closer to 1 it is, indicates greater correlation strength. In this sense, this correlation obtained a coefficient of 0.66 . This value indicates that there is a considerable correlation between the two variables analyzed.

Thus, it can be concluded that: the hypothesis formulated above can be confirmed by the correlation analysis, since this coefficient indicates that in the majority of the Brazilian States where the performance in IDH (2008) was high, a good performance in legislative electronic transparency was also found.

\subsection{Relation with the percentage of people with access to the Internet}

The Brazilian Institute of Geography and Statistics - IBGE, periodically surveys all Brazilian States with the purpose of verifying the ratio of people who have access to the Internet. This survey is taken by means of the National Research of Sampling by Domiciles - PNAD. The last survey was made in 2011, the results of which were used here to accomplish this analysis of correlation.

And considering this work to make a study of a tool that has, essentially, the Internet as its means of operation, the formulated relation has the purpose of verifying if in the states where with a greater percentage of people who have access to the Internet also possess a good performance in electronic transparency.

Accordingly, we present the graph of dispersion and the coefficient of correlation to verify the hypothesis formulated above.

Graph 02. Relation of Percentage of access to Internet X Transparency

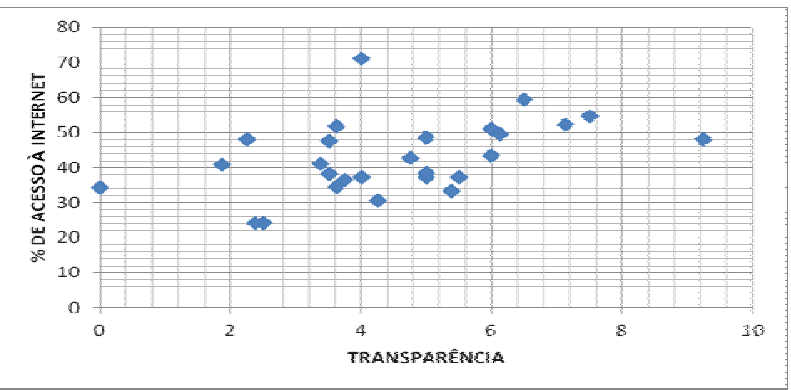

Source: Database of PNAD - 2011. Coefficient of correlation $=0.51$ 
Analyzing the graph, one can note that there is a positive correlation between the two variables, that is, the states that get high scores of $X$ tend to also get high scores of $Y$.

In the intensity test it is necessary to observe the coefficient correlation, which indicates numerically both the direction and intensity of the linear correlation. In this sense, this correlation obtained a coefficient of 0.51 . This value indicates that there is a considerable positive correlation between the two variables analyzed.

Thus, it can be concluded that: the hypothesis formulated above can be confirmed by the correlation analysis, since this coefficient indicates that in the majority of the Brazilian States where there is a greater percentage of people with access to the internet, a good performance in legislative electronic transparency was also found.

\section{Final Considerations}

This article had the intention of contributing to the improvement of the understanding of the role of the Legislatures as controlling power of the acts of the executive branch, and that therefore it has the duty of publish the actions of this power. Reaffirming that above all, the Legislature also must be transparent in its actions. This contributes to broaden the knowledge on the diverse roles of electronic government in the current public administration, in particular its use in a branch that is still little studied.

With the implantation of the electronic government, other concepts had started to be part of the modern public administration, among them e-governance, which as shown in the article, started to use Information and Communication Technology (TIC) in public administration, in its relationship with society and private institutions, be it in the operation of its means and end activities, and especially in the rendering services or making information available. Thus, it was soon noted that e-government became an important tool of accountability, uniting the rules the latter to the information technologies of the former.

However, the Brazilian experience faced right off the digital exclusion problem, which is fruit of social exclusion experienced for years in the country. This problem, certainly, left and still leaves a great part of the population on the wayside of services offered by e-gov. However, it is evident that the Country has been circumventing this question, even with governmental actions to try to diminish the number of the digitally excluded, which reaches $55 \%$ of the Brazilian population, according to data of the National Research of Sampling by Domiciles - PNAD, by the IBGE, in 2011.

Therefore, the challenges of e-gov in Brazil are still numerous. However, this article focuses on a specific branch, which is the Legislature. This direction of the study was due to the fact that few studies have been made on the application of the concepts of the electronic government in a Branch whose main role does not include the rendering of services to society, whose main role is to control the actions of the Executive Branch, besides elaborating norms and rules that govern the actions of the public administration. Thus, the use of the Information and Communication Technology - TIC in the Legislature, at the beginning, as well as in the Executive Branch, came into use for the improvement of its internal processes. However, as this Power is not a services provider, interface with the society would have to be different This form is the spreading information on its actions and also on the actions of the Executive.

However, what was observed is that Brazil proceeded rapidly with the implementation of the e-gov tools, and in the case of the legislatures, this process occurred a short time later. In the article it was possible to not that there is a great difference among the websites of this Branch, as to the availability of information, that is, there is no standard of how the information is made available in these websites, being left to the criteria of the president of the parliament to choose how these information should be made available to the public.

However, the Laws of Transparency and Access to information, even coming into effect after many countries of Latin America, sufficiently improved the amount and the quality of the information offered to citizens, since it took from the manager the discretionary power to decide whether to divulge or not certain information and defined which information should be available. The initiative, certainly, made the Brazilian State Legislatures" websites offer more information more homogeneously. It is also important to consider that the Law established deadlines for offering information, which must be followed to the letter by the managers to not result in outdated information.

Through the research it was possible to see that few states presented a satisfactory or reasonable level of transparency. When the research observed the data by geographic region it was noted, by means of the average of its respective states, that it decreases in the following direction: Southeast, South, Center West, Northeast and North. This same direction is observed when it analyzes other variables, as the IDH, and the percentage of access to the Internet in the states. When one correlated scores of the electronic transparency with the ones from IDH (2008), it was possible to see that the majority of the states with high IDH are the ones that also have a greater degree of electronic transparency. 
The same observation was made when electronic transparency and the percentage of people who have access to the Internet in the Brazilian states was correlated, that is, the states with greater percentage of access are the ones that also have the greatest degree of electronic transparency.

Therefore, in general, the legislative websites of the states Brazil, have a low level of transparency, that is, the user of these websites find little information on the researched items, with prominence for the items that evaluate the level of transparency in offering data in real time, which obtained the lowest levels of transparency.

In spite of this, the State legislature of Rio Grande Do Sul can be highlighted for presenting a satisfactory level of transparency and was by far the legislature with the highest score, which registers as the website that most meets the requirements of the Law of Transparency and Access to Information.

Therefore, the work carried out evidenced that the use of information tools in the governmental activity made possible to create more direct, institutionalized and accessible channels of access to public information, even with the persisting difficulty of access to this information by certain groups within society. And as observed, even the websites that were classified as having a satisfactory level of transparency, the information is not yet fully available. However, the opening of this information is a democratic conquest, which certainly with greater pressure and participation of society, will tend to ascent to greater levels.

\section{References}

Abramo, Cláudio Weber. Acesso a informação e eficiência do estado. Revista gov.sp, n². 2004 - Http www.transparencia.org.br lindex.html - Accessed on 10/09/2007.

Akutsu, Luiz; Pinho, José A. G. Sociedade da informação, accountability e democracia delegativa: investigação em portais de governo no Brasil. Rio De Janeiro, Rap. Set. /Out. 2002.

Chain, Ali. Et all. E-Gov - a próxima revolução brasileira. São Paulo Pearson Education Financial Times/Prentice Hall. 2004.

Clad. La responsabilizacion en la nueva gestion pública latinoamericana. Buenos Aires: Eudeba, 2000.

Commission Of The European Communities. The role of e-government for Europe's future. Brussels: Commission of the European Communities, 2003. 25 p.

Dahl, Robert A. Sobre a Democracia. University of Brasilia. Brasilia. 2001.

Keller, B. Four phases of e-government: phase 4 - Transformation. [S.I.]: GartnerGroup, 20 ten. 2000. Research Note.

Kettl, Donald. F) Corrupção em Foco: Leis Sunshine e Liberdade de Informação. In: Questões de Democracia. e-JornalUSA. Department of State of U.S.A./Dec.2006 / volume 11 / number 12. Accessible at: http://usinfo.state.gov/pub/ejournalusa.html. Accessed on: 02/20/2008.

Maia, Rousiley C.M. Redes Cívicas e Internet. In: Internet e Política. Teoria e Prática da Democracia Eletrônica. Belo Horizonte: Editora UFMG, 2002.

Mainwaring, Scott. Introduction: Democratic Accountability in Latin America. Oxford University Press, New York, 2003.

Mota. Ana C. Y. H. A. Accountabilitity no Brasil: os cidadãos e seus meios institucinais de controle dos representates. São Paulo, 2006.

Pollitt, C. Managerialism and the public service. Oxford, Blackwell, 1993.

Prado, Otávio. Governo eletrônico e transparência eletrônica: a publicização das contas públicas das capitais brasileiras. Fundação Getúlio Vargas. Rio De Janeiro, 2004.

Sanchez, Oscar Adolph. O governo eletrônico no estado de São Paulo. São Paulo, 2006.

Sarker, Partha Pratim. Governança eletrônica e em rede. In: AMBROSI, Alain; PEUGEOT, Valérie and Pimienta, Daniel (orgs.). Desafio das palavras: Enfoques multiculturais sobre as sociedades da informação. France: C\&F, 2005.

Takahashi, Tadao (org) - Sociedade da informação no Brasil- Livro Verde. Brasilia, Ministry of Science and Technology, 2000.

Vaz. José C. Administração pública e governança eletrônica: possibilidades e desafios para a tecnologia da informação. In: Governo Eletrônico - Os Desafios da Participação Cidadã. Fortaleza: Fundação Konrad Adenauer, Série Debates nº 24, Dez. 2002.

Zweers; Planqué. Eletronic Government. From an organizational based perspective towards a client oriented approach. In: PRINS, J. E. J. (ed.). Designing E-Government. Kluwer Law International, 2001. 